Emerald.

\title{
Language, translation and accounting: towards a critical research agenda
}

\section{Lisa Evans, University of Stirling \\ lisa.evans@stir.ac.uk}

\begin{abstract}
Purpose - This paper aims to increase awareness of the implications of language translation for accounting standard setting, education and research, and to work towards a critical research agenda.
\end{abstract}

Design/methodology/approach - The paper is based on a selective review of recent intercultural accounting research and literature on translation in accounting, of developments in accounting standard setting, and on selected insights from translation studies, international management and business studies.

Findings - Translation is not a simple technical, but a socio-cultural, subjective and ideological process. In contrast to the translation turn in other disciplines, however, most qualitative and critical accounting research neglects translation as a methodological and epistemological consideration and as a research opportunity.

Research limitations/implications - The paper proposes themes for a research agenda on translation in accounting.

Originality/value - The paper identifies opportunities for further and deeper investigations of translation in accounting regulation, education and research. Particular emphasis is given to the implication of translation in accounting research that is grounded in interpretivist and constructivist paradigms, where translation is inextricably linked with data analysis and interpretation and may inadvertently reproduce cultural hegemonies.

Keywords: language, translation, regulation, qualitative research, research agenda 


\section{Introduction}

Language translation is not a simple technical, but a socio-cultural, subjective and ideological process. The objectives of the present paper are to make a plea for greater awareness and more sensitive treatment of translation by accounting scholars, and to work towards a research agenda for language translation in accounting. My concern is specifically with translation between languages or between different registers of the same language - it is not with translation in a metaphorical sense, as for example in actor network theory (e.g. Callon, 1984; Latour, 1994). The paper's main argument is that translation, as well as the use of English by non-native speakers, have fundamental implications for accounting regulation, practice and research. In spite of the cultural hegemony of the English language, translation is essential: enterprises raise capital in foreign markets, engage in international transactions, manage, and incorporate the results of foreign subsidiaries and international joint ventures into consolidated financial statements, and employ and train staff from diverse cultural backgrounds. International Financial Reporting Standards and EU pronouncements are translated into a multitude of language-cultures. Accounting education is increasingly delivered - in English to non-native speakers, and international accounting researchers translate research instruments, data and findings.

However, while the translation scholar Susan Bassnett (2013, p. 1) identifies the twenty-first century as "the great age of translation", Evans and Kamla (2015) suggest that "accounting largely appears to neglect translation - both as a research opportunity and as a methodological and epistemological consideration". ${ }^{1}$ Even qualitative and critical accounting research, is, when published in English, often silent on translation (Pan et al., 2015). This is in contrast to the translation turn in related disciplines, including international business/management, and organization studies (see for example Barner-Rasmussen, Johansson and Śliva, 2017; Marschan et al., 1997; Marschan-Piekkari et al., 1999; Tietze et al., 2014). One of the reasons for this neglect in accounting research appears to be the adoption of the equivalence paradigm: the assumption that the transfer of meaning and concepts between languages and cultures is a simple technical process of exchanging terms that are equivalent. This paper draws on recent literature in translation studies to argue that such a equivalence rarely exists - instead, equivalence is a fiction: "natural equivalence can be described as illusory and deceptive" (Pym 2014, p. 21; 1992a/2010, p. 47).

The paper explores the implication of such insights from translation studies and from recent research in international business/management on translation in accounting regulation, education and research. It further specifically explores the practical and ideological implications of translation of qualitative data from other language-cultures (see for example Komori, 2015; Xian, 2008). It argues that especially interpretative paradigms need to be aware of, and acknowledge, these implications. This will impact on our research methods and findings, but also provide rich avenues to explore for further research. The main aim of this paper is to draw attention to such research opportunities.

The remainder of this paper is structured as follows: Building on literature from translation studies, the next section provides an exploration of the concept of equivalence in translation, and of the alternative, that is the use of English as lingua franca (ELF). This is followed by an examination of translation and ELF in international accounting standard setting and implementation. The subsequent section deals briefly with translation and ELF in accounting education, and the final major section with translation and ELF in qualitative accounting research. This section also explores implications of translation for research on accounting and gender and for critical accounting research, as well as for the translation of theoretical frameworks. The final section concludes, and summarises specific research opportunities relating to the implication of translation for accounting regulation, education and research. 


\title{
Equivalence and ELF
}

\author{
Equivalence
}

"Despite decades of academic and professional translation research, the traditional parameters configuring the equivalence paradigm persist. It has for a long time not only helped identify translation and its ethics of neutrality, but guided pedagogies. When scholars translate survey questionnaires, and journalists transfer news, when foreign businesses discuss contracts, and viewers watch subtitled TV programs, or when language teachers use back-translation, they all rely heavily on the equivalence paradigm-language differences are considered errors, distortions in meaning." (Gambier 2016, p. 889)

Accounting practice and policy-makers frequently convey the assumption that a form of objective accounting reality can be transferred from one language-culture to another, without change in meaning. Such a traditional equivalence paradigm is also assumed in most accounting research (see below). Surprisingly, this applies not only to positivist empiricist and rationalist epistemologies - the latter suggesting that meanings and ideas "are universal and thus generally translatable into their various language-specific representations" (Pym and Turk, 2001, p. 273), but also to qualitative accounting research grounded in relativism and constructivism. (There are of course exceptions - many of which will be referred to below.)

This narrow understanding of equivalence is based on "an illusion of symmetry between languages" (Snell-Hornby, 1988, p. 22), a belief that "a text to be translated is nothing more than a linear sequence of words or phrases" (Gambier, 2016, p. 888). However, the relationship between languages is not one of simple symmetry. Words may be absent in some languages, or convey different meanings (Gambier, 2016). Finnish, for example, can be much more nuanced when speaking about different types of snow than many other languages; the same applies to Arabic with reference to the behavior of camels, to English with respect to light and water, and to French with regard to bread (Bassnett, 2003, p. 37). Kinship and colour terms are frequently used in linguistics to illustrate differences between languages and cultures. For example, the Italian term nipote can be translated into English as "nephew", "niece", or "grandchild" (Eco, 2003, p. 23-5); and a wealth of research in linguistics and psychology provides evidence of a lack of one-to-one equivalence in colour terms (and perception) between different language communities (e.g. Lucy and Shweder, 1979; Robertson et al., 2000; Winawer, 2007). Connotations of colour also differ - death is associated with black in Western, and with white in Eastern cultures (Pym, 2014, p. 7). Similarly, while a term may be found to translate "bathroom" from English into Japanese or Finnish, the cultural connotations differ widely (Catford, 1965/80).[2] As a result, something is almost always lost (or gained) in translation (see e.g. Bassnett, 2003, p. 36-7; Eco, 2003, p. 32-61). In fact, "translation is a balancing act" (Kettunen, 2016, p. 41).

In translation theory, the concept of equivalence is "variously regarded as a necessary condition for translation, an obstacle to progress in translation studies, or a useful category for describing translations" (Kenny, 2001, p. 77). A definition of equivalence in the widest sense may be that

"what we say in one language can have the same value (the same worth or function) when translated into another language. The relation between the start text and the translation is then one of equivalence ('equal value') where 'value' can be on the level of form, function, or anything in between. Equivalence does not say that languages are the same, it just says that values can be the same" (Pym, 2014, p. 6, emphasis original) [3]. 
However, equivalence has been defined and classified in different ways, with overlapping demarcations and terms. Most of the limited research on language translation in accounting is concerned with linguistic equivalence, which refers to attempts to achieve homogeneity of source and target texts on the linguistic level (Bassnett, 2003, p. 32, with reference to Popovič, 1976) [4].

Pym (2014) classifies theories of (linguistic) equivalence into two sub-paradigms: directional equivalence and natural equivalence. The latter developed as a reaction to structuralist linguistics, which sees languages as systems, reflecting fundamentally different world-views [5]. Ultimately, this means that equivalence in translation should not be possible (Pym, 2014, p. 9). However, in practice, translation does occur. Proponents of natural equivalence therefore assume equivalence to exist at levels below those of language systems. Natural equivalence thus refers to an underlying common notion that has the same function in different languages. A natural equivalent term would be the term assumed by speakers of each language as the most usual to express this function (Pym, 2014, pp. 8-9). Natural equivalence also assumes that translation is not affected by directionality - the result should be the same regardless of which one of two languages is the source, and which the target language. Natural equivalence is therefore "close to what many translators, clients, and end-users believe about translation" (Pym, 2014, p. 6). In practice, however, natural equivalents appear to exist almost exclusively as artificially created technical terms that are intended to correspond in different languages. They are created in specialized fields of knowledge, which have specific terms (Kade, 1968; Pym, 2014, p. 12), i.e. their own specialized jargons, registers, or languages for specific purposes (LSPs).

Where natural equivalents cannot be identified, applied linguistics has developed several practical approaches and solutions, from closeness to the source text to closeness to the target culture. They include literal translations, loan words, adaptations and explication. However, all either add to, or reduce the source text message. In addition, these solutions and underlying theories normally work well only between cognate languages, but not between unrelated languages, as for example English and Chinese (or Japanese) (Pym 2014, pp. 12-16).

An alternative paradigm is directional equivalence. This assumes that the relationship between source and target language is not symmetrical. Therefore, a translator must choose between several possible terms in the target language, none of which will completely correspond to the term in the source language. As a result, back translation of a translated text into the original source language will not normally result in a text identical to the source text, nor would two translators create identical translations (Pym, 2014, p. 24). (A simple example would be to use the IFRS Foundation's Terminology Lookup to translate "revenue" into Japanese. The translation offered is 収益; if this is then back translated, the result is "income" - suggesting a lack of a natural equivalent, in this case [6].)

By contrast with natural equivalence theories, directional equivalence is less concerned with practical solutions. Instead it distinguishes between two distinctly different approaches to translation: "free" and "literal", although these have been conceptualized in many different ways. For example, Schleiermacher (1813/1963) distinguished between "foreignizing" and "domesticating" translations (see also below) and Nida (1964)[7] between "formal equivalence" and "dynamic equivalence" (Pym, 2014, p. 30-1). Pym (2014, p. 32) provides other examples of such polarity, but argues that the ideology imbedded in this is "deeply anchored in Western nationalism" (Pym, 2014, p. 34), assuming a "cultural and linguistic border" (Pym, 2014, p. 24). In essence, directional equivalence assumes that there are many different ways of achieving equivalence, but none of them in the complete and symmetrical way assumed by natural equivalence. 
An alternative to translation is the use of a lingua franca. In spite of its multilingual language policy, the EU's working practice has increasingly turned towards ELF: In 1997 the EU had 15 member states and 11 official languages. The official working languages were French, English and German. The majority of documents (including accounting directives) were drafted in French (Dollerup, 1997). In 2017 the EU has 28 member states and 24 official languages [8]. French, English and German are still the official working languages, but in 2009, $72.5 \%$ of all source texts were drafted in English (11.8\% in French, 2.7\% in German) (House, 2016, p. 112). Many of the texts drafted in English are not drafted by English native speakers, but written in ELF (House, 2016, p. 112).

The dominance of ELF is not limited to the EU. English is spoken by approximately four times as many non-native speakers than native speakers, and therefore "can be said to be no longer owned by its native speakers" (House, 2016, p. 112). The IASB uses English as a working language, and while the majority of its (senior) staff may be native speakers, this does not apply to all, nor to the majority of the board members, or the Accounting Standards Advisory Forum representatives, and certainly not its constituents.

Linguists differ in their assessment of the usefulness of ELF. House argues that ELF benefits from functional flexibility and from its wide geographic spread. Further, as the main objective is efficient and effective communication, correctness is not important, and speakers can dispense with culturally or historically embedded idioms and "other routinized phrases full of insider cultural-historical and national references invariably based on national tradition, convention or class" (House, 2016, p. 112).

Snell-Hornby (2010), on the other hand, considers what she refers to as "Globish/American/British" (the GAB), "Eurospeak" and "McLanguage" as "the reduced, interference-bound system of verbal communication based on a low common denominator of the English code basically comprehensible to those with some knowledge of English" (SnellHornby, 2010, p. 18), which has only limited utility in other than relatively basic communication acts. In any case, the use of ELF has cognitive and ideological implications. Tietze (2004) argues that the global use of ELF and global management discourse share tacit assumptions and (Anglo-Saxon) ideological foundations that together encourage and perpetuate specific forms of global capitalism, consumerism and commerce.

Further, the use of ELF may impede original thinking and cognitive processes, is closely associated with social and group identity, and with exclusion and power (Evans et al., 2015, Harzing and Feely, 2008; Karhunen and Kankaanranta, 2017), this also applies in business schools (Śliwa and Johansson, 2014). Language may be perceived as part of national identity and as "one of the major factors used to categorize others, possibly more important than ethnicity as it is an acquired characteristic and hence provides a more powerful indication of a person's identity" (Harzing and Feely, 2008, p. 52; see also Temple, 2013, p. 106). In multinational organisations, a gap exists between two levels of English - the ELF spoken in everyday interactions among employees, and the more formal English used in official communications. This gap can contribute to inequality (Karhunen and Kankaanranta, 2017). In addition, differences in (English) language skills can affect communication flows and networks; greater language skills can be a source of power and facilitate the creation of broader networks (Marschan-Piekkari, 1999). According to Harzing and Feely (2008), communicating in a foreign language (including ELF) can lead to misunderstandings and create, maintain and reinforce group boundaries. Language barriers engender vicious circles, in which failure to communicate effectively creates uncertainty, anxiety and mistrust, which may lead to 
misattribution, conflict and cognitive distortion. This, in turn, can give rise to greater formality in communication, which then results in even less effective communication (Harzing and Feely, 2008).

\section{Translation and ELF in Standard Setting and Implementation}

$E L F$

"Do you think Chinese make the same judgements as Americans - I do not think so" (Pan et al., 2015, p. 487, interview extract)

The use of ELF also affects creative thinking and cognitive processes in accounting regulation, education, practice and research (e.g. Gendron and Humphries, 2015; Holthoff et al., 2015; Komori, 2015; see also below). As argued by Evans et al. (2015, p. 27), "[i]f discourse is predominantly in English, lack of English language competency has practical, academic, social, and status implications". In particular, unequal (English) language skills can disadvantage and disenfranchise individuals (and nations) in the legislative or standard-setting process (e.g. Dollerup 1996; Evans et al. 2015; Hjelström 2005). For example, Dollerup (1996, p. 300, quoted in Evans et al., 2015) cites a frustrated national delegate in EU negotiations, p. "we say what we are able to say, not what we wish to say".

Hjelström (2005, p. 351-2) suggests that the authority of individuals involved in the IASC standard setting process (specifically, in the case of IAS 12, 1996, [9]) depended, inter alia, on language and cultural proficiency, and that poor (English) language skills contributed to the relatively low engagement of some of the steering committee members. Most did not have a good command of English.

But even when language competency is high, individuals will process information differently in their native, versus foreign languages. Based on prior research in psychology and other health-related disciplines, Pan and Patel (2016) suggest that individuals make systematically different (ethical) judgments in their first and second languages, with second language use leading to utilitarianism and greater emphasis on cost-benefit considerations and economic well-being. This results in more aggressive judgments than that which would result from native language processing. While this effect is not confined to specific languages, the languages themselves also affect information processing differently: simplified Chinese encourages an interdependent cultural mind-set, but English an independent cultural mindset. The latter is likely to lead to more optimistic information processing and more aggressive judgment. Pan and Patel (2016) provide empirical evidence, from an accounting case study experiment, that supports the above findings of prior research in other disciplines.

\section{Accounting Regulation and Translation}

"[I]ndeterminacy will never completely go away"

(Pym, 2014, p. 87, with reference to Quine, 1960).

Even if ELF is widely embraced, the concerns outlined above, and in particular differences in English language/ELF proficiency, suggests that high quality, timely translation is essential for IAS/IFRS implementation and accounting change (e.g. Abd-Elsalam and Weetman, 2003; Larson and Street, 2004). The translation of IFRS is managed or undertaken both by the IFRS Foundation and by the EU [10]. Who controls these processes, and which regulatory authorities 
are involved, does matter. In fact, the EU and the IFRS Foundation's different translation policies and processes represent "a contested area of expertise involving multiple, recurrently changing constituents" (Kettunen, 2017, p. 38).

The IFRS Foundation acknowledges that translation is vital in achieving its aim to develop a single set of global accounting standards (IFRS Foundation website [11]). However, IFRS may be difficult to understand, even in English. (An example, from IFRS 5, is provided below). This makes them difficult to translate (e.g. Wong, 2004). Problems also include translation errors [12] and "soft transformations" - the deliberate exploitation, in translation, of the inherent ambiguity of accounting terms (Ordelheide, 1990). An even more complex problem is that of (the lack of) equivalence.

As noted above, natural equivalence occurs almost exclusively in technical LSPs, where terms have been specifically created, or defined, in specialised fields of knowledge (Kade, 1968; Pym 2014, p.12). Equivalence in such LSPs may however be restricted to disciplines (such as engineering) that are less culture-dependent, and where terms are not inherently indeterminate (Evans et al., 2015). It is a more complex issue for disciplines such as accounting or law, where terms rooted in long-established traditions coexist or compete with new terms created in harmonization attempts (such as the IASB's terms) [13].

Although accounting may be deemed at least in part a technical variety of language, many accounting concepts are culturally dependent and socially constructed; they overlap in function or form but are not strictly (natural) equivalents in different accounting traditions. For example, the Dutch concept geeft een getrouw beeld is not exactly equivalent to "present fairly" (or "give a true and fair view") (Zeff, 1990), and "target costing" only partly captures the meaning of the Japanese strategic cost management practice genkakikaku (Komori, 2015). This lack of equivalence is the focus of the majority of prior research on translation in accounting. (See Baskerville and Evans, 2011; Dahlgren and Nilsson, 2012; Evans, 2004; Kettunen, 2017 for further examples).

However, if we use the nearest perceived equivalent in translation, this may either lead a user of this translation to assume full (i.e. natural) equivalence, or, at best, result in generalisation, or a loss of subtle (but significant) differences (Evans, 2004). For example, if the German term Wirtschaftsprïfer is translated as Chartered Accountant, a reader unfamiliar with the German context will assume greater congruence between a German auditor and a British Chartered Accountant (in terms of education, qualification, occupational tasks, occupational culture and regulatory framework) than actually exists. The shift in meaning inherent in these translations may not be appreciated: "It is as if the presence of an apparently viable verbal label actually blinds the subject to reality. He sees only what the words lead him to expect and does not respond to the objective situation" (Jain, 1973, p. 100, drawing on Luchins (1942)). A (non-accounting) example is provided by Bassnett (2003, pp. 38-9) with the term "democratic":

"The problem here is that the reader will have a concept of the term based on his or her own cultural context, and will apply that particularized view accordingly. Hence the difference between the adjective democratic as it appears in the following three phrases is fundamental to three totally different political concepts:

the American Democratic Party

the German Democratic Republic

the democratic wing of the British Conservative Party

So although the term is international, its usage in different contexts shows that there is no longer (if indeed there ever was) any common ground from which to select situational features" (Bassnett, 2003, p. 39). 
A different problem in the quest for suitable translations of technical terms is the complete absence of a comparable concept in the target culture, requiring the creation of a new term (or adoption of a loan-word) when the concept it imported. However, as noted by Zeff (2007), if an accounting concept is introduced into an accounting culture to which it is entirely alien, the concept will not be understood, regardless of which words are chosen to denote it. A widely discussed example relates to the difficulties that arose in translating "true and fair view" when this concept, which originated in and is closely linked to the UK accounting tradition and common law legal system, was introduced into code law and Continental European accounting systems (see for example Alexander, 1993; 1996; Aisbitt and Nobes, 2001; Ordelheide, 1993; 1996; Nobes, 1993; Rutherford, 1983). As Pym notes, such imports introduce new information into the target language, which means that there can be no "natural" equivalents:

"If translations are supposed to bring in information that is new to a language or culture, then they cannot be expected to be 'natural'. Since new things will eventually require new terms and expressions, the translations are going to be marked in ways that their start texts are not. This argument usually becomes a question for terminology: should the translation use loans from the start text, or should new terms be invented from resources considered 'natural' in the target language?" (Pym, 2014, p. 19) [14]

Kettunen (2017) points out that one-to-one equivalence in IFRS terminology is usually constructed during translation. More than one potential source language term is often suggested as a possible translation, supporting the claim that natural equivalence is rare. In the translations into Finnish, new coinages as well as borrowings from English were used if no suitable target language terms could be found. However, new Finnish coinages were sometimes found to be incomprehensible. In addition, connotative meaning between the English and the Finnish terms could differ (Kettunen, 2017).

In addition to the partial but incomplete equivalence of concepts in different accounting traditions and the complete absence of some concepts in some traditions, translation of accounting regulation is also affected by a further potential problem: the translation and interpretation of everyday, generic, i.e. non-technical terms, in accounting rules.

Such terms may include, for example, "terms of likelihood" (also referred to as uncertainty or probability expressions) - expressions such as likely, probable, virtually certain, unlikely, or remote. These are widely used in IFRS. For instance, EFRAG's (2013) Uncertainty Bulletin discusses uncertainty, and the judgement required to deal with uncertainty, in the IASB's conceptual framework. It provides the following examples of uncertainty expressions in the standards

"Probable is defined in IAS 37 and IFRS 5 as more likely than not. IAS 37 states that this interpretation of probable does not necessarily apply to other standards, IFRS 5 does not include this caveat. In practice, the term probable in other standards has been interpreted as meaning something other than more likely than not. For example, IAS 12 has been interpreted as allowing the use of a higher threshold than more likely than not when it requires future tax profits to be probable for the recognition of deferred tax assets" (EFRAG, 2013, para.8, emphases added)

According to IFRS 5, assets are classified as held for sale if the sale is "highly probable". As noted in Ernst \& Young's (2015, p. 149) International GAAP 2016

"Many observers may consider the meaning of 'highly probable' to be reasonably selfevident, albeit highly judgmental. However, IFRS 5 provides extensive discussion on 
the topic. As a first step, the term is defined by the standard as meaning 'significantly more likely than probable'. This is supplemented by a second definition - probable is defined as 'more likely than not'. [IFRS 5 Appendix A]. Substituting the latter into the former leads to a definition of highly probable as meaning 'significantly more likely than more likely than not'.... In the particular context of classification as held for sale, the IASB evidently did not consider that 'significantly more likely than more likely than not' was an adequate definition of the phrase, so the standard goes on to elaborate ..."[15]

Ambiguity and uncertainty in interpretation is of course not limited to translation, but part also of communication between speakers of the same language. This is, for example, demonstrated for accounting, by several concept perception studies conducted in the 1970s and 1980s (Adelberg, 1979; Adelberg and Farelly, 1989; Haried, 1972, 1973; Oliver, 1974). While the above IFRS example may appear extreme, a certain degree of ambiguity is intended, since in the Anglo-American accounting tradition, flexibility is required to permit accountants to exercise professional judgement when applying accounting standards, conceptualised as principles rather than rules. This is related to the concept of linguistic hedging, which refers to words or constructions intended to tone down the force of statements or to qualify the commitment to statements made by deliberately introducing vagueness; they include inter alia expressions of uncertainty and of probability (Crompton, 1997; Li and Haque, 2016).

Translations into other languages should, ideally, reflect the same ambiguity and scope for judgement as the English language original, and result in equivalent interpretations. However, the above critique of the equivalence paradigm suggests that this is unlikely to occur in practice. This suggestion is supported by empirical research, which finds that interpretations of uncertainty expressions in translation differ from those of the English original (e.g. Davidson and Chrisman, 1993; 1994; Doupnik and Riccio, 2006; Doupnik and Richter, 2003; 2004; KASB and AASB, 2016 [16]). More recently, Kettunen (2017) provides interview evidence about IFRS translation into Finnish that suggests that the same degree or nuance of ambiguity can often not be preserved in translation. In addition, the interpretation of probability expressions in IFRS by bicultural individuals appears to depend on the language in which they read the IFRS (Huerta et al., 2016).

In addition, a preference for flexibility and judgement, and their inherent ambiguity, is not universally shared (Pan et al., 2015). Pan et al.'s Chinese interview subjects expressed a preference for quantifiable benchmarks:

"I cannot understand why the standard setters use words such as 'probable', 'reasonable' and 'control' in accounting standards? Why can't they simply give us the specific percentage? This will improve comparability and consistency of information within and across countries. Additionally, I will not make mistakes by referring to the specific percentage. Judgements are subjective and confusing" (Pan et al., 2015, p. 487, interview extract).

Similar concern was expressed with regard to the ambiguity of the control criterion in IFRS 3 , the standard for business combinations. In addition, in the Chinese cultural and political context, the inherent indeterminacy of terms such as "control" was further complicated by ideological implications:

"Control reminds me of the strict control at home, strict control at school, strict control at university and strict control of my boss at part-time work. Our society is all about control. The government virtually controls all our activities. I cannot possibly be objective when you ask me to apply the meaning of control to accounting. The word 'control' is highly emotional and this emotion is attached to the meaning of control in 
any context. I do not think any Chinese people can be objective when they apply the word 'control' in any context" (Pan et al. 2015, p. 487).

Thus the wider cultural context of the target language - including the political context, will affect translation. This made translation of international standards into Chinese "a big challenge both technically and politically" (Ezzamel and Xiao, 2015, p. 67). Ezzamel and Xiao provide a further example:

"At the beginning of the development of the accounting regulation for IJV [International Joint Ventures], when many people heard the word 'capital', they did not feel comfortable. Because they have been under the influence of Maoist education for so many years, they could not accept foreign ideas and concepts. This naturally created debate and even resistance which in turn distracted and delayed reforms"

(Interview extract in Ezzamel and Xiao, 2015, p. 67)

These observations support the argument made by Bassnett with the example of the term "democratic" (see above).

The aim of the IASB's translation team is to established "a translation process with the objective of ensuring a high-quality translation that accurately reflects the meaning of the original English" (IFRS Foundation, 2013, p. 5, emphasis added). In summary, given the above observations about equivalence, ambiguity, ideology and the choices required to be made in translation, this aim of uniformity and accuracy in translation appears ambitious. This is also noted by Kettunen (2017, p. 43): "the goal of ensuring accuracy compared with the English source text seems an ideal lacking a clear path to its realisation”.

For financial reporting in practice, more ambiguous qualities are encouraged, such as faithful representation (not accuracy) and comparability (not uniformity). Thus while accounting practitioners and standard setters acknowledge the subjectivity and judgment associated with financial reporting, such awareness appears to be lacking for the ambiguities and biases inherent in language and translation.

\section{Translation and ELF in accounting education}

"[T]he translation of these standards is a big obstacle for learning about the standards. Those who cannot go back to the English source like me ... are finding it very difficult to understand them and therefore pass the exam" (Gallhofer et al., 2011, p. 387, interview extract).

Accounting education, and in particular taught post-graduate courses, are increasingly delivered in English in countries where English is not the official or main language. Frequently, students whose first language is not English are taught by academic staff whose first language may or may also not be English. An advantage of learning in ELF is that it may prepare students for a work environment increasingly dominated by ELF. On the other hand, however, the language in which we learn affects cognition and information processing. This, in turn, affects performance and academic achievement (Holthoff et al., 2015). Based on prior research and their own investigations, Holthoff et al. (p. 120) argue that

"confronting students with accounting texts in English may have negative effects if students lack sufficient English language skills. Especially students participating in introductory courses on IFRS are likely to find it difficult to understand the subject of accounting when the standards are not presented in their mother tongue. This is 
particularly important for countries in which students start their studies with a low level of English language skills".

Apart from the direct impact on learning, language, in education, also has ideological implications. As argued by Tietze (2004, p. 184) with reference to international management, "the effects of English as a global language and management discourse as an increasingly dominant source of meaning and action mutually reinforce each other", supported by shared ideologies and universal truth claims. Therefore, "the mastery of English combined with a conquest of the interpretive frames of the management discourse is a potent source of power which reproduces the world in line with the assumptions of their mutually reinforcing ideologies" (ibid.).

Language, in education, can even lead to (racial) exclusion. This was, for example, shown by Hammond et al. (2009) for South Africa. Hammond et al. found that in apartheid South Africa, racial exclusion was not only overt, but also based on language competencies (cf. Murphy, 1988). Black South Africans who spoke non-dominant languages at home were disadvantaged and excluded in education and at work, but exclusion affected not only black South Africans: poor quality translations also put Afrikaans speakers at a disadvantage. Thus, in South Africa, "[1] anguage was used intentionally as a political weapon" and "[c]losure based on language permeated the apartheid and post-apartheid eras ..." (Hammond et al. 2009, p. 715).

Teaching students international accounting in local languages may overcome this problem, but this requires high quality translation of teaching material - either translations of textbooks originally produced in English, or textbooks directly based on IFRS in English, or in translation. In any case, on some level, translation has to occur. This translation has to deal with the challenges outlined above: the lack of equivalent concepts, as well as the inherent vagueness of some accounting concepts and of the generic language that is part of IFRS, including probability expressions (see e.g. Baskerville and Evans, 2011).

Poor quality translations contribute to the creation of uneven playing fields in employment and education. This is noted by one of the interviewees in a study by Gallhofer et al. (2011, p. 387):

“... With due respect, the person who translated IASs to Arabic has not done a great job. Try to read them in Arabic and you'll understand nothing. I tried to read them a few times (preparing for the CA exam) and did not understand what they are trying to say. ... I didn't understand a thing, as their translation is very bad".

While management research has begun to critically engage with the role of language, Tietze (2004) argues that this has not been embraced by management education. She thus encourages academics to take the linguistic turn into the classroom.

\section{Translation and ELF in accounting research}

"Translation involves power differences between language users and countries and resulting ethical and political considerations about how to represent others, not just the mechanics of changing words into another language" (Temple 2013, p.102)

Research quality has increasingly become associated with publication in English language, and usually North American, academic journals. While academic globalisation may carry 
"the promise of "knowledge without frontiers", [a] more pessimistic position views academic globalization as the handmaiden of the global imposition of Western academic cultures. ..., it signals the hegemony of theories, methodologies, and styles of thinking and writing identified with particular academic cultures of the North Atlantic" (Waisboard, 2016, p. 870)

Although Waisbord (2016) suggests that encounters of academic cultures are really more complex than either of these positions suggest (see below), it may be argued that as a result of such globalisation, academic research increasingly fails to engage with local concerns (Burawoy, 2005; Humphrey and Gendron, 2015). It also means that English has become the lingua franca of research and academic publishing.

'These assumptions of 'English only publication practices' are based on a belief that the English language is a universal language, able to express all truth and experiences.' Tietze, S., 2018.

However, "the role of English in knowledge production is not a neutral one" (Tietze, 2018, p. $? ?)$.

For non-native speakers, the pressure to publish in English-language journals raises several concerns. These include costs for translation and language editing services (Humphrey and Gendron, 2015). Alternatively, writing directly in ELF may force non-native speakers to over-simplify ideas and limit their ability to innovate "since skills at playing with words, concepts and metaphors play a key role in the emergence of new ideas" (ibid., p. 53-4). Tietze and Dick (2013) suggest that, in the academic management community, failure to publish in English is attributed to individual failure to achieve a sufficiently high standard of language proficiency. As argued by Snell-Hornby (2010), while the use of ELF may have some utility in simple communication acts, it is "unsuitable for sophisticated forms of communication" such as academic conferences and publications (Snell-Hornby, 2010, p. 18). Conventions of academic discourse differ significantly, even between related languages and cultures such as English and German. When non-native speakers attempt to write in English, while retaining their own and discursive traditions, the results may be incomprehensible (Snell-Hornby, 2010). The need to publish in English may also mean that non-native speakers may be disadvantaged in, or excluded from, academic discourse; it may even shape academic disciplines and agendas (Humphrey and Gendron, 2015; Komori, 2015; Snell-Hornby, 2010; Waisbord, 2016) [17]. In essence, the dominance of English, and the demand to meet specific standards of English, privileges native speakers (Lillis and Curry, 2015). Re the role of editors, reviewers etc. the impact of editorial policies and the role of gatekeepers of international journals (editors, editorial board members, reviewers, etc.) 'In the light of strongly emerging debates about the role of the English language, a consensus based on more forgiving, flexible standards that would not compromise mutual intelligibility needs to be discussed.' Tietze, S., 2018.

Research in linguistics critically explores this inequality in power between languages for non-literary genres. Bennett (2006; 2007; see also Munday, 2013, p. 137)) even suggests that the dominance of English in academic writing has led to "epistemicide", which eliminates or at least dominates other traditions. As a result, the intended internationalisation of research does in fact lead to Anglocentrism and homogenization of research, to the creation of linguistic hierarchies, linguistic marginalisation, and linguistic apartheid (Humphrey and Gendron, 2015, see also Steyaert and Jannsen, 2013). 
"The processes of translation involved in making another culture comprehensible entail varying degrees of violence, especially when the culture being translated is constituted as that of the "other"'(Dingwaney, 1995, p. 4)

A very large proportion of qualitative accounting research published in leading accounting journals draws on data from diverse national and cultural settings, worldwide. Research methods employed include interviews, oral histories, case studies, content analysis, surveys, experiments or focus groups. Where the first language of research subjects or the language of written data sources is not the language of publication, translation is required. This may involve translation of interview questions or guides, survey instruments, or case scenarios for experimental research design. Where data analysis is conducted in a language other than English, the research findings will have to be translated for publication in English. Alternatively, interviews, focus groups or experiments are frequently conducted in English even if this is not the subjects' first language, thus shifting the onus of translation onto the subject. This is frequently the case in spite of the constraints of ELF in more complex communication acts (see above), and in spite of evidence from psychology on the effect of first versus second language on information processing and ethical judgement (e.g. Pan and Patel 2016, see above) [18]. Further, interviewees present themselves differently in different languages (Temple, 2013). Burton's (2003) oral history interviews suggest that the language in which interviews are conducted (English or Japanese) affects power relationships as well as the nature and content of the interviews. This is because, compared to English, Japanese is "hierarchical, less direct and more gendered" (Temple, 2013, p. 101, with reference to Burton, 2003). According to Burton (2003, p. 45) "what constitutes a truth in Japanese may well be different, or at least differently voiced, than one in English". However, in accounting and management, researchers rarely discuss the implications of translation [19] - in fact, the translator is frequently invisible (cf. Venuti, 1995/2008).

Instead, translation appears to be subject to the positivist assumption of an objective reality that can be translated into an equivalent objective reality in other languages. This implies that the translator's role is a purely technical, objective one and that problems can be overcome by means of specific "scientific" methods, such as back translation (Xian, 2008). This also applies to the translation of research instruments. However, back translation does not solve the problem of equivalence (Chidlow et al., 2014 [20]; Douglas and Craig, 2007; Kettunen, 2017; Pan et al., 2015).

In international business, Welch and Piekkari (2006, based on Alvesson) found that international business researchers conducting qualitative interviews are likely to reflect one of three main epistemological and ontological positions: neopositivism/objectivism, interpretivism and social constructivism. Depending on the researcher's position, language choice is perceived to affect data accuracy (objectivism); data authenticity - resulting from a relationship of trust between interviewer and interviewee (interpretivism); or contextually grounded, inter-relational data - resulting from the development of shared understanding between interviewer and interviewee (social constructivism). For example, data accuracy was perceived to be affected when interviewing non-native speakers in English: "some managers would use 'corporate English' - in other words, the English they heard in the workplace and used to perform their professional roles. This often meant repeating company policy and falling back on jargon, rather than being confident enough to formulate extended and individualised responses." (Welch and Piekkari, 2006, p. 428). ${ }^{21}$

Based on interpretative content analysis of qualitative and survey-based quantitative research published in four international business journals, Chidlow et al. (2014) found that quantitative research usually relies on back translation, which is often assumed to assure 
equivalence, which in turn is associated with 'accuracy, validity, reliability and research quality. It is not clear however what is understood by equivalence, as the term is not used uniformly. Language differences are considered to be errors that can be eliminated or controlled. Chidlow et al. also found that the majority of qualitative research was silent on translation. This, it is argued, would be in keeping with conventions of 'scientific' reporting, which is silent on the researcher's role, but not with the call for greater reflexivity in reporting qualitative research findings (see e.g. Haynes, 2012).

'In the literature on qualitative cross-language methodology (which is currently largely based in nursing and sociology, with little infl uence on management research), the equivalence paradigm has also been influential.' Chidlow et al., 2014

The translation of qualitative data, in particular, is highly problematic - it cannot be assumed, that "cultural elements can be carried across unchanged in the translation process" (Xian, 2008, p. 232), nor that "all ways of viewing the social world can be straightforwardly captured using the English language" (Temple, 2013, p. 100). Xian identifies linguistic, cultural and methodological problems, which are interrelated. Linguistic problems relate to the lack of equivalence between languages (see above). This is especially relevant when a subject or discipline - such as accounting - is culture-specific, socially constructed, inherently indeterminate or ideological (Evans, 2004; Evans et al., 2015).

Socio-cultural problems arise from the difficulty, for Xian (2008, p. 235), of the "translation of Chinese idioms and proverbs, which originated from Chinese historic stories and mythologies, and complex social phenomena" (Xian, 2008, p. 235). If these are translated literally, they are meaningless; if they are explained, they result in a text that is less concise, "clumsy", and further removed from the original [22]. The translator therefore has to recreate a socially constructed reality in another language-culture, balancing the need to convey indigenous concepts and knowledge in English, against the risk of over-domesticating the text (Xian, 2008); the latter - encouraged by Anglo-American translation tradition (Venuti, 1995/2008) - would permit a more fluent style, but risk compromising the concepts and knowledge to be conveyed (Xian, 2008; see also Komori, 2015). Over-domesticating a text creates an illusion of naturalness, disguising the fact that the text in question is a translation. Translating idioms and expressions with the nearest equivalents in the target language produces a network of cultural references relating to the target culture (Munday, 2013, p. 148, with reference to Berman, 1985/2004). An example would be the translation of the German Wirtschaftsprïfer as Chartered Accountant. Not only would a reader unfamiliar with the German context assume greater congruence between these concepts than actually exists - as argued above - but such over-domestication affects "the way major cultures see the rest of the world. If all cultures are made to sound like contemporary fluent English, then AngloAmerican culture will believe that the whole world is like itself" (Pym, 2014, p. 20; Venuti $1995 / 2008$; 1998). Pym argues, therefore, that naturalness is ethnocentric, hides imperialism and promotes parochialism (Pym, 2014, pp. 20, 100).

In any case, the translation of qualitative data is a sensitive process. The analysis of such data involves interpretation, and the process of translating across languages and cultures adds an additional dimension to an already subjective process. This means also that two translators are unlikely to interpret the same source text in the same way (Xian, 2008). As the researcher's/translator's (unconscious) biases will affect the translation (Evans et al., 2015; Temple, 2006), the process is not value free; "like any cultural practice, [it] entails the creative reproduction of values" (Venuti, 1998, p. 1). However, as argued by Xian (2008, p. 242) "to recognise the translator's presence in a piece of research is no different from recognising the 
presence of the research and the research subjects". She therefore argues for a more reflexive and interpretative approach, which acknowledges that translation is a messy process, and acknowledges the translator's role in constructing reality: "The translation process constitutes a (re)construction of the social reality of a culture in a different language, in which the translator interacts with the data, actively interpreting social concepts and meanings" (Xian, 2008, p. 233).

\section{Accounting research, translation and gender}

"It is difficult for a woman to define her feelings in language which is chiefly made by men to express theirs" (Bathsheba Everdene, in Far From the Madding Crowd,

Thomas Hardy)

Insights from the interface between translation, culture and gender studies may also be useful to interdisciplinary and intercultural accounting research. This literature includes a feminist paradigm (see for example Simon, 1996), which takes a deliberate political and ideological stance.

On a more pragmatic level, language (also in the context of the accounting profession) may differ between that of men and women. For example, Haynes (2013, p. 386) notes that there is a differences in language choice inherent in the power relations in an accounting firm. With reference to Spender (1980), Haynes argues that the separation between male and female, and the continued silence of women, is ensured by means of "choice of language which does not accommodate some of the meanings women may want to articulate, inappropriate male controlled registers, male controlled sanctions for language use, and sexist use of language" (Haynes, 2013, p. 386). In fact,

"[t]he power of language choice in this accounting firm became a symbolic expression of male dominance over women in the organisation who were excluded from this masculine informal bonding process and more significantly from control and authority within the firm" (Haynes, 2013, p. 386)

Similarly, Kyriacou (2016, p. 55) argues that "the Greek language has been utilised by the profession to articulate its privileges and position" and calls for future research to "explore how the use of the (Greek) language can render women invisible by the prioritisation of certain words over others". How do we capture such differences in the use of language in translation?

Giving voice to gendered experiences may be particularly sensitive if we translate into English (as frequently representing a dominant culture). In her translation of the experiences of Chinese women, Xian noted that she had gone too far in domesticating indigenous knowledge: "I realized that what I had translated about Chinese women's careers was not much different from literature about Western careers. ... I was rewriting them to conform to the styles and themes that currently prevail in the target culture" (Xian, 2008, p. 237). This phenomenon is critically explored by Spivak, who challenges expectations of western feminists that feminist writings in other languages should be translated into English (Munday, 2008, Chapter 8). Spivak argues that

"[i]n the act of wholesale translation into English there can be a betrayal of the democratic ideal into the law of the strongest. This happens when all the literature of the Third World gets translated into a sort of with-it translatese, so that the literature by a woman in Palestine begins to resemble, in the feel of its prose, something by a man in Taiwan" [23] (Spivak, 1993/2004, pp. 371-2, emphasis added). 
This resonates with Komori's (2015) experiences about trying to give meaning to the accounts of Japanese women practicing accounting, for a Western audience. Komori argues that it was difficult to convince reviewers who lacked knowledge of the Japanese context of the validity of her findings. This was because these findings did not translate easily into non-indigenous that is specifically Anglo-Saxon - concepts and assumptions, especially about the role and power of women:

"There is an inherent risk that the phenomena will be miscommunicated or misinterpreted, and an inherent pressure for the experiences and perspectives identified to be moulded so as to legitimize Anglo-Saxon-led assumptions and problem-setting" (Komori, 2015, p. 151).

I will return to the ideological implications of this problem below. Before doing so, another, at first sight more technical problem to be explored, is that many languages are not gender neutral but mark gender through the use of gender-specific nouns, pronouns or grammatical structures. One challenge in translation is to render gender-neutral terms into a language where the apparently closest translation is not gender-neutral. For example the German term Mensch is, in theory, gender-neutral in that it can refer equally to women and men. It may, and now frequently is, translated into English as "human being" or "person". However, older English translations frequently rendered the term as "man" - as also in the compound Menschheit, usually translated as "mankind" (less commonly as "humankind" or "humanity"). For example, where Max Weber's Economy and Society refers to der kultivierte Mensch, the English translation uses "cultivated man" (Weber, 1968, p. 1001). In addition, many languages have a grammatical gender which may tax translators as well as native speakers. Oltermann (2014) cites Mark Twain: "In German, a young lady has no sex, while a turnip has. Think what overwrought reverence that shows for the turnip, and what callous disrespect for the girl".

In Germany, the implication of the grammatical gender is now critically discussed, as is the difference in occupational titles for men and women. All state bodies are now required to use gender neutral language, which has given rise to controversial coinages (Olderman, 2014). For auditors, the mid-1990s saw a change in the law regulating the audit profession, which means that there is now a female version of the title (Wirtschaftsprïferin), which women may choose to adopt (or not). Where both men and women are referred to, a variety of new alternative forms have been introduced, such as WirtschaftsprüferInnen, Wirtschaftsprüfer/innen, Wirtschaftsprüfer(innen), Wirtschaftsprüfer und Wirtschaftsprüferinnen. English, on the other hand, uses different policies to address the same issue: it appears to be losing the markers for terms that distinguish between male and female, as for example in the names of occupations. We see the term "actor" now used for women and men, based on the perception that "actress comes into the same category as authoress, comedienne, manageress, 'lady doctor', 'male nurse' and similar obsolete terms that date from a time when professions were largely the preserve of one sex (usually men)" (Pritchard, 2011). As these linguistic issues are, in the case of both languages, driven by political motives, the researcher/translator faces challenges beyond the purely linguistic.

In addition, 'gender marking' provides opportunities for research. Quantitative research in international business and human resource management has explored, for example, the link between a language's grammatical gender marking on the one hand, and staffing decisions and women's presence in corporate management on the other hand (Malul et al., 2016; SantacreuVasut, Shenkar, and Shoham, 2014). The argument made in this research is that gender marking is particularly deeply embedded in culture (Johansson, 2005) and that stronger gender marking in a language is associated with poorer socio-economic outcomes for women (Malal et al. 
2016). While the attempt to quantify grammatical structures deterministic - agency, constructivism - see Tietze (2004)

\section{Translation and Ideology}

“... translation is a highly manipulative activity that involves all kinds of stages in that process of transfer across linguistic and cultural boundaries. Translation is not an innocent, transparent activity but it is highly charged with significance at every stage; it rarely, if ever, involves a relationship of equality between texts, authors or systems" (Bassnett and Trivedi, 1999, p. 2)

Ideology [24], in the context of translation and accounting, has been referred to above and also discussed elsewhere. (Foreign) language skills constitute cultural, or more specifically, linguistic capital (Bourdieu, 1991). This endows speakers with prestige, authority and power (Xu and $\mathrm{Xu}, 2008$ ), and, as discussed above, advantages English native speakers in academic publishing. In a standard setting context, constituents with lesser English language competencies may be disenfranchised, and the IASB consultation process and dissemination of its pronouncements may be controlled by the most powerful stakeholders - such as the Big Four international audit firms. In addition, translation in accounting regulation and practice is "vulnerable to cognitive and cultural bias, to a vested exploitation of indeterminacy in language and to ideologically and pragmatically motivated distortions" (Evans et al., 2015, p. 28). In fact, translation, as well as language competencies, may reflect very unequal power relations. This is reflected in

\footnotetext{
"What gets translated (what is valued and what is excluded)? Who does the translation (who controls the production of translation)? Who is translated for (who is given access to foreign materials and who denied)? How is the material translated (what is omitted, added, altered, to control the message)?" (Fawcett, 2001, p. 107, with reference to Nord, 1988/91).
}

These questions invite us to further reflect on, for example, who decides what is worth translating, and what budgets can be allocated. Whose ideological biases may influence the translation? These are themes for Critical Discourse Analysis, which considers translation "as a process that is inevitably influenced by the power differences between participants" (House 2016, p. 25; see also Munday, 2007).

We may further ask which languages are deemed important enough to be source or target languages for translation, and which are not. There are differences in power between languages themselves (Niranjana, 1992; Spivak, 1993/2004; both in Munday, 2013), which we have seen, for example, reflected in the dominance of ELF (cf. House, 2016, pp. 26-7). This leads some authors to speak of linguistic imperialism, which may be defined as "the process by which speakers of one language come to find it necessary to use another language, 'to the point where they believe they can and should only use that foreign language when it comes to transactions dealing with the more advanced aspects of life"' (Blenkinsopp and Pajouh, 2010, p. 39; citing Ansre, 1979).

Power relations are also central to the intersection between translation studies and postcolonial theory (Basnett and Trivedi, 1999; Munday, 2013, p. 203) [25]. As argued by Niranja (1992), translation's modes of representing the other may reinforce hegemonic representations of the colonised. Similarly, Temple (2013) argues that colonialism is reinforced unless it is acknowledged that language is part of identity, and that speakers of languages other than English may perceive the world differently. 
Given the concern of critical accounting research with the subaltern and imperialism [26], translation should also be an important theme in interdisciplinary and critical accounting research. However, with regard to such research, Komori $(2015$, p. 150), critically questions

"whether voices from non-Anglo-Saxon contexts are in fact only allowed to speak when they accord with Western assumptions (Chua, 1998; Kim, 2008). My experience raises questions about the extent to which (Western-led) international accounting research decides what can be heard and what cannot".

Such critical explorations of translation are reflected in the cultural turn in translation studies (see below).

\section{Using Foucault (and Weber, and Bourdieu and ...) in translation}

"The sociology of academic knowledge has demonstrated that scholarly work is moored in specific institutionalized contexts of production. From Karl Mannheim (1936) to Pierre

Bourdieu (1984), this line of research has shown how social positions and institutional logics shape knowledge and ideas. Scholars are not free-floating producers of knowledge; they are members of specific academic tribes with their own rules and cultures"

(Waisbord, 2016, p. 873)

One additional concern is the use of ideas and theoretical frameworks that originate in languages other than English. Bruno Bettelheim (1982) famously argued that mistranslation of Sigmund Freud's work into English has led to the failure of American psychoanalysis. Yet while accounting research draws on, for example, the seminal works of Marx, Weber, Foucault, Bourdieu, or Habermas, the impact of translation on these works is rarely discussed. (The same applies in international management (Tietze, 2018)).

An obvious problem is delay. Annisette and Richardson (2011) note that, while Luc Boltanski and Laurent Thévenot's work had transformed French sociology since the publication of De la justification: Les économies de la grandeur in 1991, two decades later it had not yet made a significant impact on research in accounting. One reason for this was that Catherine Porter's English translation On Justification: Economies of Worth was only published in 2006. However, there are more significant concerns than the delay in accessing new insights in other disciplines, since

“... translations inevitably transform to some extent the original text. Reading Michel Foucault in French, for instance, is not exactly the same as reading the English translation. The meaning is sometimes different, and the esthetics of the text, for sure, are not the same" (Humphrey and Gendron, 2015, p. 52)

A more detailed and very insightful examination of the inherent complexity of translating Foucault is made by Hoskin (2016, see also Hoskin, 2015 and Spivak, 1993). Similar issues arise with the translation of other authors. For example, as noted in the introduction to the English edition of Weber's Economy and Society, the original German text "is full of irony, sarcasm and the love of paradox; a dead-pan expression may imply a swipe at the Kaiser, statusconscious professors or pretentious littérateurs", but: "[i]ronic formulations and wordplays are hard to render in translation" (Roth, 1968, p. XXXIV). Roth (1968, p. CVIII) also notes that the writing style differs, allowing Weber to use German syntax to better effect than is feasible with English. In addition, specific terms prove difficult to translate. For example, the term Evidenz, as used by Weber, cannot be simply translated as "evidence" in English. Instead, the 
1968 translation uses the phrase "clarity and veritable accuracy of insight and comprehension" to capture the single German term, but, as noted in the accompanying footnote, this is an imperfect translation since there is no real equivalent for Evidenz in English, and it is therefore translated in different ways throughout the text, depending on context. These different translations include also "certainty", "clarity" and "accuracy" (Weber, 1968, pp. 5, 58). Concerns relating to a lack of equivalence also arise with translations of other key terms in Weber's sociology, such as Herrschaft, Stand, Gemeinschaft and Gesellschaft (frequently translated, respectively, as "authority" or "domination", "status group", "community", and "society" or "association") (Clegg and Lounsbury, 2009; Evans, 2017; Waters and Waters, 2010). These examples should suffice to illustrate that regardless of the quality of the translator's work, the translation of these sociological texts are not equivalent to the originals.

Inevitably these problems increase where translation occurs across non-cognate languages. Thus Yang et al. (2015) observe a loss of meaning when Western-based theories have been used to inform Chinese corporate environmental reporting research. The issue goes deeper, of course, than a simple lack of equivalent terminology: it is rooted in the historically different national characters of academic disciplines and theories (Waisbord, 2016) [27]. As argued by Waisbord (2016, p. 877),

\begin{abstract}
"The strength of national factors explains long-term tendencies that precede the current push to internationalization, such as the hybridization of theoretical frameworks as local academics adapt 'traveling theories' (Said, 1983) to domestic concerns and/or blend them with indigenous insights. ... global connectivity among academic cultures fosters unpredictable dynamics that result from blending and rearticulation of theories, concepts, and methods. 'Lost in translation' is always a possibility when theories leave their original home" [28].
\end{abstract}

However ... 'Czarniawska (2007: 28) in a reflection on the future of Organization Theory and the dominance of scholars in North America and Europe, refers explicitly to the problem of translation as organization theory travels across the globe; she remarks that 'Anglo-Saxon works are translated on a massive scale, but almost no original research is being done' (as is happening in Eastern Europe and Russia).' Steyaert, C. and Janssens, M., 2013.

\title{
Concluding comments: towards a research agenda
}

\author{
"The field of translation studies has succeeded in deconstructing both the conventional \\ definition and the image, and now embraces creativity, voice, interpretation, \\ commitment, and an ethics of responsible subjectivity" (Gambier, 2016, p. 888, with \\ reference to Sun, 2014)
}

Language translation is of fundamental importance in international accounting - for practice, regulation, education and research. However, accounting has paid far less attention to translation than other academic disciplines. With few exceptions, the accounting discipline seems to assume a traditional equivalence paradigm, a notion of direct equivalence between different languages. Natural equivalence suggests that, from the same source text, two translators would create the same target language text. However, as argued above, "... natural equivalence can be described as illusory and deceptive" (Pym, 2014, p. 21). It exists almost exclusively in LSPs, that is, in (usually artificially created) terms for specialized fields of knowledge, such as medicine or engineering. Accounting, as a technical subject, contains such specialist and closely defined terms, which for IFRS are artificially constructed and negotiated (Kettunen, 2017). However, accounting language also represents a discipline that is behavioural in nature, and inherently indeterminate. As such it contains terminology that is 
shared with everyday language and with the LSPs of other disciplines, and the meaning of which is highly ambiguous and not universal across different accounting cultures.

The reliance on a paradigm of natural equivalence seems surprising, therefore, in accounting practice and regulation, which assert that accounting itself is ambiguous, principlesbased, and requires professional judgment. The assumption of natural equivalence appears to be even more surprising in research that relies on naturalistic methods and is grounded in relativism, in interpretivist and constructivist paradigms. While such research embraces the notion that knowledge, and our view of the world, are socially constructed and therefore not universally comparable across different settings, times and cultures, this notion is frequently disregarded when it comes to translation, across language-cultures, in the context of this research.

According to Pym (2014, pp. 37-8) equivalence is based on shared historical conventions, partly simply because this is cost-effective. Equivalence thus is "a fiction, a lie, a belief-structure necessary for the workings of [some] economies and the survival of [some] societies" (Pym 1992/2010, p. 47). To address the lack of natural equivalence, indeterminacy, and other problems with conventional approaches to translation, the discipline of translation studies has deconstructed the traditional conception of equivalence and replaced it with other paradigms (Gambier, 2016), including descriptive translation studies (Toury, 1995/2012), Skopos theory (Reiss 1986; Reiss and Vermeer 1984; 1991; 2013; Vermeer, 1978) [29], and a more socio-cultural understanding of translation (Bassnett and Lefevere, 1990; Venuti, 1995/2008) which acknowledges that meaning is culturally embedded and requires interpretation, a process that is inevitably subjective (Gambier, 2016). It has also embraced indeterminacy (e.g. Quine, 1969), which is seen to be compatible with theories of hermeneutics, constructivism, game theory and deconstruction (see Cronin, 2001; Pym, 2014, Chapter 6). Many of these theoretical approaches have been applied in accounting research, albeit rarely with reference to language translation. What most of these alternative paradigms have in common is a turn away from predominantly linguistic approaches towards sociocultural and contextual considerations and to acknowledge that "translation always involves transformation" (Pym, 2014, p.107). Perhaps of most significance for qualitative, in particular interdisciplinary and critical accounting research, is therefore the cultural turn in translation studies, that is the move away from text to the interface between translation and culture, as well as politics (Snell-Hornby, 1990), or, in the words of Bassnett and Lefevere (1990, p.11), to "the larger issues of context, history and convention".

The themes explored in this paper suggest that further systematic studies are required on the impact of translation and non-translation (i.e. the use of ELF) in accounting. As noted by Kettunen (2017, p. 53), "... we have very little insight into the views of those who prepare, use and audit financial statements on the approaches they adopt to address the practical problems involved in handling linguistic equivalence in the context of their daily work, or into the negotiations on the degree of discretion possible with specific translations" (Kettunen, 2017, p. 53). For international standard setting and implementation, themes to be explored include the impact of unequal language skills among board and committee members, and the impact of translation on dissemination, implementation and interpretation of international standards. There is scope for further research, for example, on the effect of the ambiguity of accounting language in translation into different language cultures, in particular those with less judgement-based accounting traditions. Apart from financial reporting and standard setting, the impact of translation on accounting practice is also highly relevant for strategic, managerial reporting, for performance evaluation, and for audit judgement. There is also scope to learn from and collaborate with scholars in related disciplines (such as international business/management, and organization studies), which have embraced language research for at least the last two decades. 
There is also scope for deeper exploration of the limitations and problems associated with the use of ELF (Snell-Hornby, 2010), but also its potential utilities (House, 2016) and its impact on shaping academic communities and agendas. Particularly useful would be interdisciplinary research, drawing on insights from or collaborating with colleagues in linguistics and psychology to enhance our understanding of the cognitive and ideological implications of ELF. ELF is also relevant for accounting education, and there is scope for further research on the implications of teaching and learning in ELF, as well as of the impact of translation on understanding and interpretation of accounting regulation, and on the quality of translations into different languages. The contribution of translation and of ELF to the wider dissemination of accounting knowledge, but also to the creation of uneven playing fields, privileged elites and to professional closure, provide further opportunities for research. Exploration of the impact of editorial policies and the role of gatekeepers of international journals (editors, editorial board members, reviewers, etc.) on publication by non-native English speakers, on the evolution of manuscripts, and on the implications for knowledge production (Lillis and Curry, 2006, 2015) ... . Institutional stakeholders, gatekeepers, editors, reviewers, can change or influence editorial policy.

More generally, for both accounting regulation and education, we may also wish to reflect on what is translated, and for whom.

An additional theme, not discussed above, is the translation that occurs in communication across different LSPs within the same language. For example, Rogowski (1994) notes that German "[1]awyers and accountants communicate in different languages. They apply different codes to select types of communication as either legal or economic" (Rogowski, 1994, p. 19). Such differences between LSPs apply also in English (e.g. Evans, 2010; Parker, 1994).

Perhaps the most interesting impact of translation for the academic community in accounting relates to its linguistic, cultural and methodological implications (cf. Xian, 2008) in the context of qualitative research. There is scope to draw on the insights generated from the cultural turn in translation studies; thus, for example, accounting researchers can critically explore further how translation may lead to the reproduction of values and of cultural hegemonies (cf. Spivak, 1993/2004; Venuti, 1998), especially when research across languages is silent on translation. There are ideological and ethical implications in the balancing act, discussed by Xian (2008) and Komori (2015), between over-domesticating research findings in translation to make them accessible to readers unfamiliar with the source culture, and convincing Western audiences of their validity. The need to comply with non-indigenous expectations about agendas and findings (Komori, 2015) may explain why even critical accounting research, concerned with gender and the subaltern, is often silent on translation, and may risk thereby reinforcing "hegemonic versions of the colonised" (Niranja, 1992, p. 3). This goes hand in hand with silences in feminist accounting research, as this also is dominated by Western voices (e.g. Gallhofer, 1998); it also has implication, in particular, for ethnographic research and interview and oral history methods, where translation contributes to the concerns highlighted for example by Kim (2008):

"The very methodology of the oral history method re-enforces hegemonic Western ideologies about race/ethnicity, gender and class perpetuated through the connection between the cultural identity of the speaker and the notion of authenticity as a ground for academic authority" (Kim 2008, p. 1346; see also Haynes, 2010, p. 221; Temple, 2013)

Leading on from this, accounting research can also more widely draw upon insights from the interfaces with gender studies, cultural studies and post-colonialism. There is, more 
specifically, scope for research on how language choice and grammatical structures impact on gender roles and power relations between men and women, and how and to what extent we can capture this in translation. Further, we may wish to explore the implications of language change driven by political agendas (such as that relating to gender-neutral language). Finally, there is scope for exploring what is lost (or gained) in the translation of the theoretical frameworks we employ. How different, for example, may be the conclusions based on an application of Foucault or Bourdieu, between a Francophone and an Anglophone accounting researcher? What opportunities may there be for theory-building ... see above ... .

In summary, the aim of this paper was to increase awareness of methodological and epistemological implications of translation in accounting, and as a research opportunity. Specifically, it aimed to draw attention to the implications of translation for accounting standard setting, education and research, and to work towards a critical research agenda. Inevitably, it suffers from limitations, in that it is based only on a selective review of recent accounting research and of developments in accounting standard setting, and only on selected insights from translation studies and other disciplines. In concluding, it is safe to argue that translation is not a simple mechanical and neutral activity. If we use it in our intercultural research - and in particular if we apply interpretive paradigms - we need to be mindful of its implications. This has repercussions for our research methods, but it also provides avenues for informing and enriching accounting research.

\section{References}

Abd-Elsalam, O. H. and Weetman, P. (2003), "Introducing international accounting standards to an emerging capital market: relative familiarity and language effect in Egypt", Journal of International Accounting, Auditing and Taxation, Vol. 12 No.1, pp. 63-84.

Adelberg, A.H. (1979), "A methodology for measuring the understandability of financial report messages", Journal of Accounting Research, Vol. 17 No. 2, pp. 565-92.

Adelberg, A.H. and Farrelly, G.E. (1989), "Measuring the meaning of financial statement terminology: a psycholinguistics approach", Accounting \& Finance, Vol. 29 No.1, pp. 33-61.

Aisbitt, S. and Nobes, C. (2001), "The true and fair view requirement in recent national implementations", Accounting and Business Research, Vol. 31 No.2, pp. 83-90.

Alexander, D. (1993), “A European true and fair view?", European Accounting Review, Vol. 2 No.1, pp. 59-80.

Alexander, D. (1996), "Truer and fairer. Uninvited comments on invited comments", European Accounting Review, Vol. 5 No. 3, pp. 483-493.

Annisette, M. and Richardson, A.J. (2011), "Justification and accounting: applying sociology of worth to accounting research", Accounting, Auditing \& Accountability Journal, Vol. 2 No. 4, pp.229249.

Ansre, G. (1979), "Four rationalisations for maintaining European languages in education in Africa", African Languages, Vol. 5 No. 2, pp. 10-17.

Athanassiou, P. (2006), "The application of multilingualism in the European Union context", European Central Bank Legal Working Papers Series No. 2, February.

Barner-Rasmussen, W., Johansson, M., and Śliva, M. (2017) "Call for papers. Sub-theme 22: Organizations, Language/s and Mobility/ies", $33^{\text {rd }}$ European Group for Organizational Studies Colloquium, available at https://www.egosnet.org/jart/prj3/egos/main.jart?rel=de\&reservemode $=$ active \& content-id $=1493586858301 \&$ subtheme_id=1442568082210 $\quad$ (accessed $\quad 1$ August 2017).

Baskerville, R., and Evans, L. (2011). The Darkening Glass: Issues for translation of IFRS, ICAS, Edinburgh, available at https://www.icas.com/ data/assets/pdf file/0004/10588/11-TheDarkening-Glass-Issues-for-Translation-of-IFRS-ICAS.pdf (accessed 1 August 2017).

Bassnett, S. (2003), Translation Studies, $3^{\text {rd }}$ edition, Routledge, London and New York.

Bassnett, S. (2013) Translation (The New Critical Idiom), Routledge, Abingdon and New York.

Bassnett, S. and Trivedi, H. (1999), Postcolonial Translation: Theory and Practice, Routledge, London and New York. 
Bassnett, S. and Lefevere, A. (1990), Translation, History and Culture, Pinter, London and New York. Baugh, B. (2003), French Hegel: From Surrealism to Postmodernism, Routledge, Abingdon and New York.

Berman, A. (1985), "La traduction comme épreuve de l'étranger in Traduction: Textualité,, Texte, Vol. 4, pp.67-81.

Blenkinsopp, J. and Shademan Pajouh, M. (2010), "Lost in translation? Culture, language and the role of the translator in international business", Critical Perspectives on International Business, Vol. 6 No.1, pp.38-52.

Boltanski, L. and Thévenot, L., (1991). De la Justification. Les Économies de la Grandeur, Gallimard, Paris.

Bourdieu, P. (1984), Homo Academicus, Minuit, Paris.

Bourdieu, P. (1991), Language and Symbolic Power, Harvard University Press, Cambridge, MA.

Burawoy, M. (2005) "For public sociology - 2004 Presidential Address", American Sociological Review, Vol.70 No.1, pp. 4-28.

Burton, S. (2003) "Issues in cross-cultural interviewing: Japanese women in England", Oral History, Vol.31 No.1, pp 38-46.

Callon, M. (1984), "Some elements of a sociology of translation: domestication of the scallops and the fishermen of St Brieuc Bay", The Sociological Review, Vol. 32 No.1, suppl, pp.196-233.

Carnegie, G.D. and Wines, G.L. (1992), "Inconsistent standard setting: the case of asset recognition criteria in Australia (1970 to 1992)", Accounting History, Vol.4 No.2, pp.22-32.

Catford, C. J. (1965/1980), A Linguistic Theory of Translation: An Essay in Applied Linguistics, Oxford University Press, London.

Chua, W. F. (1998), "Historical allegories: let us have diversity", Critical Perspectives on Accounting, Vol. 9 No.6, pp.617-628.

Crompton, P. (1997), "Hedging in academic writing: some theoretical problems", English for Specific Purposes, Vol. 16 No. 4, pp. 271-287.

Cronin, M. (2001), "Game theory and translation", in Baker, M. (Ed.), Routledge Encyclopedia of Translation Studies, Routledge, London \& New York, pp. 91-93

Cunico, S. and Munday, J. (2007), "Encounters and clashes: Introduction to translation and ideology", The Translator, Vol.13 Issue 2, pp.141-149.

Dahlgren, J. and Nilsson, S-A. (2012), "Can translations achieve comparability? The case of translating IFRSs into Swedish", Accounting in Europe Vol.9 No.1, pp.39-59.

Dahrendorf, R. (1959), Class and Class Conflict in Industrial Society, Stanford University Press, Stanford.

Davidson, R. A. and Chrisman, H. H. (1993), "Interlinguistic comparison of international accounting standards: The case of uncertainty expressions", International Journal of Accounting, Vol.28 No.1, pp.1-16.

Davidson, R. A., and Chrisman, H. H. (1994), "Translations of uncertainty expressions in Canadian accounting and auditing standards" Journal of International Accounting, Auditing and Taxation, Vol. 2 No.3, pp.187-203.

Dingwaney, A. (1995) "Translating 'third world' cultures", in Dingwaney, A. and Maier, C. (Eds), Between Languages and Cultures: Translation and Cross-Cultural Texts, University of Pittsburgh Press, Pittsburgh and London, pp. 3-15.

Dollerup, C. (1996), "Language work at the European Union", in Rose, M. G. (Ed.) Translation Horizons Beyond the Boundaries of Translation Spectrum, Translation, Center for Research in Translation, State University of New York at Binghamton, Binghamton, pp. 297 - 314.

Douglas, S.P. and Craig, C.S. (2007), "Collaborative and iterative translation: An alternative approach to back translation", Journal of International Marketing, Vol.15 No.1, pp.30-43.

Doupnik, T. S. and Riccio, E. L. (2006), "The influence of conservatism and secrecy on the interpretation of verbal probability in the Anglo and Latin cultural areas", The International Journal of Accounting, Vol.41 No.3, pp.237-261.

Doupnik, T. S. and Richter, M. (2003), "Interpretation of uncertainty expressions: A cross-national study”, Accounting, Organizations and Society, Vol. 28 No.1, pp.15-35. 
Doupnik, T. S. and Richter, M. (2004), "The impact of culture on the interpretation of "In-Context" verbal probability expressions", Journal of International Accounting Research, Vol.3 No.1, pp.1-20.

Eco, U. (2003), Mouse or Rat? Translation as Negotiation, Weidenfeld \& Nicolson, London.

Ernst \& Young (2015) International GAAP 2016. Generally Accepted Accounting Principles Under International Financial Reporting Standards, Wiley.

European Financial Reporting Advisory Group (EFRAG) (2013), Getting a Better Framework. Uncertainty Bulletin, EFRAG, Brussels.

Evans, L. (2004), "Language translation and the problem of international accounting communication", Accounting Auditing and Accountability Journal, Vol.17 No.2, pp. 210-248.

Evans, L. (2010), "Observations on the changing language of accounting", Accounting History, Vol.15 No.4, pp.439-462.

Evans, L. (2017) "Shifting strategies: the pursuit of closure and the 'Association of German Auditors", European Accounting Review, forthcoming, available online http://dx.doi.org/10.1080/09638180.2017.1329658

Evans, L. and Kamla, R. (2015), "Language and Translation in Accounting”, Special issue call for papers for Accounting, Auditing \& Accountability Journal.

Evans, L., Baskerville, R., and Nara, K. (2015), "Colliding Worlds: Issues Relating to Language Translation in Accounting and Some Lessons from Other Disciplines", Abacus, Vol. 51, No.1, pp. 1-36.

Ezzamel, M. and Xiao, J.Z. (2015), "The development of accounting regulations for foreign invested firms in China: The role of Chinese characteristics", Accounting, Organizations and Society, Vol.44, pp.60-84.

Fawcett, P. (2001), "Ideology and translation", in Baker, M. (Ed.) Routledge Encyclopedia of Translation Studies, Routledge, London and New York, pp. 106-111.

Gallhofer, S. (1998), "The silences of mainstream feminist accounting research", Critical Perspectives on Accounting, Vol.9 No.3, pp.355-375.

Gallhofer, S., Haslam, J. and Kamla, R. (2011), "The accountancy profession and the ambiguities of globalisation in a post-colonial, Middle Eastern and Islamic context: Perceptions of accountants in Syria”, Critical Perspectives on Accounting, Vol.22 No.4, pp.376-395.

Gambier, Y. (2016), "Rapid and radical changes in translation and translation studies", International Journal of Communication, Vol.10, pp.87-906.

Hammond, T., Clayton, B. M. and Arnold, P. J. (2009), "South Africa's transition from apartheid: The role of professional closure in the experiences of black chartered accountants", Accounting, Organizations and Society, Vol.34 No.6/7, pp.705-721.

Hardy, T. (1874), Far from the Madding Crowd, Penguin Longman.

Haried, A.A. (1972), "The Semantic Dimensions of Financial Statements", Journal of Accounting Research, Vol.10 No.2, pp. 376-91.

Haried, A.A. (1973), "Measurement of Meaning in Financial Reports", Journal of Accounting Research, Vol.11 No.1, pp. 117-45.

Harzing, A.W. and Feely, A.J. (2008), "The language barrier and its implications for HQ-subsidiary relationships", Cross Cultural Management: An International Journal, Vol.15 No.1, pp.49-61.

Haynes, K. (2008), "(Re)figuring accounting and maternal bodies: The gendered embodiment of accounting professionals, Accounting, Organizations and Society, Vol.33 No.4, pp.328-348.

Haynes, K. (2010), "Other lives in accounting: critical reflections on oral history methodology in action", Critical Perspectives on Accounting, Vol.21 No.3, pp.221-231.

Haynes, K. (2013), "Sexuality and sexual symbolism as processes of gendered identity formation: An autoethnography of an accounting firm", Accounting, Auditing \& Accountability Journal, Vol.26 No.3, pp.374-398.

Hjelström, A. (2005) Understanding International Accounting Standard Setting - A case study of the process of revising IAS 12 (1996), Income Tax, unpublished PhD Thesis, Stockholm School of Economics.

Holthoff, G., Hoos, F. and Weissenberger, B.E. (2015), “Are we lost in translation? The impact of using translated IFRS on decision-making", Accounting in Europe, Vol.12 No.1, pp.107-125. 
Hoskin, K. (2016), "Getting to the surface of things: Foucault as theorist and historian of management and accounting", draft book chapter, University of Birmingham.

Hoskin, K. (2015), “'What about the box?' Some thoughts on the possibility of 'corruption prevention', and of 'the disciplined and ethical subject", Critical Perspectives on Accounting, Vol.28, pp.71-81.

House, L. (2016), Translation as Communication across Languages and Cultures, Routledge, London and New York.

Huerta, E., Petrides, Y. and Braun, G.P. (2016), "Interpretation of probability expressions in accounting: The effects of frame switching", Journal of International Accounting, Auditing and Taxation, Vol. 27, pp.1-12.

Huerta, E., Petrides, Y. and Braun, G.P. (2013), "Translation of IFRS: Language as a barrier to comparability", Research in Accounting Regulation, Vol. 25, No. 1, pp.1-12.

Humphrey, C. (2008), "Auditing research: a review across the disciplinary divide", Accounting, Auditing \& Accountability Journal, Vol.21 No.2, pp.170-203.

Humphrey, C. and Gendron, Y. (2015), "What is going on? The sustainability of accounting academia", Critical Perspectives on Accounting, Vol.26, pp.47-66.

IFRS Foundation (2013) Translation, Adoption \& Copyright Policy, available at http://www.ifrs.org//media/feature/standards/translations/translation-adoption-copyright-policy2013.pdf?la=en\&hash=F47B41756F154B92770B6BB14C4E399256474FE2 (accessed 1 August 2017).

Jain, T.N. (1973), "Alternative methods of accounting and decision making: a psycho-linguistic analysis", Accounting Review, Vol. 48, pp. 95-104.

Kade, O. (1968), Zufall und Gesetzmäßigkeit in der Übersetzung, VEB Verlag Enzyklopädie, Leipzig.

Karhunen, P. and Kankaanranta, A. (2017) "Towards inclusive and participatory language policies in multinational corporations: A sociolinguistic approach to English as corporate language", paper presented at the $33^{\text {rd }}$ EGOS Colloquium, 6-8 July 2017, Copenhagen.

KASB and AASB (Korean Accounting Standards Board and Australian Accounting Standards Board) (2016) Accounting Judgments on Terms of Likelihood in IFRS: Korea and Australia. KASB Research Report No.39 / AASB Research Report No.2. July 2016

Kenny, D. (2001), "Ideology and Translation", in Baker, M. (Ed.) Routledge Encyclopedia of Translation Studies, Routledge, London \& New York, pp. 77-80

Kettunen, J. (2017), "Interlingual translation of the International Financial Reporting Standards as institutional work, "Accounting, Organizations and Society", Vol. 56, pp.38-54.

Kim, S. N. (2008), "Whose voice is it anyway? Rethinking the oral history method in accounting research on race, ethnicity and gender", Critical Perspectives on Accounting, Vol.19 No.8, pp.1346-1369.

Komori, N. (2015), "Beneath the globalization paradox: Towards the sustainability of cultural diversity in accounting research", Critical Perspectives on Accounting, Vol. 26, pp.141-156.

Kyriacou, O. (2016), "Accounting for images of 'equality' in digital space: towards an exploration of the Greek accounting professional institute", Critical Perspectives on Accounting, Vol. 35, pp.35-57.

Larson, R. K. and Street, D. L. (2004), 'Large accounting firms' survey reveals emergence of 'Two Standard' system in the European Union, Advances in International Accounting, Vol.17, pp. $1-29$.

Latour, B. (1994), "On technical mediation, philosophy, sociology, genealogy", Common Knowledge, Vol.3 No.2, pp. 29-64.

Li, Z. and Haque, S. (2016), "Linguistic Hedging in CSR Disclosures - Evidence from Employeerelated Disclosures", working paper, Queensland University of Technology, Brisbane.

Luchins, A. S. (1942), "Mechanization in Problem Solving: The Effects of Einstellung", Psychological Monographs, Vol. 54 No. 6, pp. i-95.

Lucy, J.A. and Shweder, R.A. (1979), "Whorf and his critics: linguistic and nonlinguistic influences on colour memory", American Anthropologist, Vol. 81, pp. 581-615.

Mannheim, K. (1936), Ideology and Utopia, International Library of Psychology, Hove, UK.

Marschan-Piekkari, R., Welch, D., \& Welch, L. (1997), "Language: The forgotten factor in multinational management," European Management Journal, Vol. 15 No.5, pp.591-598. 
Marschan-Piekkari, R., Welch, D. and Welch, L. (1999), "In the shadow: The impact of language on structure, power and communication in the multinational", International Business Review, Vol. 8 No.4, pp.421-440.

Munday, J. (2007), "Translation and ideology: A textual approach", The Translator, Vol.13 No.2, pp.195-217.

Munday, J. (2008), Introducing Translation Studies, Routledge, Abingdon and New York.

Murphy, R. (1988), Social Closure: The Theory of Monopolization and Exclusion, Clarendon, Oxford.

Niehus, R. J. (2005), "Die IFRS auf Deutsch, Fehler und Unzulänglichkeiten der Übersetzung", Der Betrieb, Vol. 58, pp. 2477-2483.

Niranjana, T. (1992), Siting Translations: History, Poststructuralism and the Colonial Context, University of California Press, Berkeley and Los Angeles.

Nobes, C. and Parker, R.H. (2010), Comparative International Accounting, Financial Times/Prentice Hall, Harlow.

Nobes, C. (1993), "The true and fair view requirement: Impact on and of the fourth directive", Accounting and Business Research, Vol.24, pp.35-48.

Nobes, C. (2013) "The continued survival of international differences under IFRS", Accounting and Business Research, Vol.43 No.2, pp.83-111.

Nord, C. (1988/1991), Text Analysis in Translation: Theory, Methodology and Didactic Application of a Model for Translation-oriented Text Analysis, Rodopi, Amsterdam and Atlanta.

Oliver, B.L. (1974), "The Semantic Differential: A Device for Measuring the Interprofessional Communication of Selected Accounting Concepts", Journal of Accounting Research, Vol.12 No.2, pp. 299-316.

Oltermann, P. (2014), "Germans try to get their tongues around gender-neutral language", The Guardian, 24 March 2014, available at https://www.theguardian.com/world/2014/mar/24/germans-get-tongues-around-genderneutral-language

Ordelheide, D. (1990), "Soft-transformations of accounting rules of the 4th Directive in Germany", Les Cahiers Internationaux de la Comptabilité, Vol. 3, pp.1-15.

Ordelheide, D. (1993), "True and fair view. A European and a German perspective", European Accounting Review, Vol.2 No.1, pp.81-90.

Ordelheide, D. (1996), "True and fair view. A European and a German perspective II", European Accounting Review, Vol.5 No.3, pp.495-506.

Pan, P. and Patel, C. (2016), "The influence of native versus foreign language on Chinese subjects' aggressive financial reporting judgments", Journal of Business Ethics, forthcoming, available online DOI 10.1007/s10551-016-3165-z

Pan, P., Patel, C. and Mala, R. (2015), "Questioning the uncritical application of translation and backtranslation methodology in accounting: evidence from China", Corporate Ownership and Control, Vol. 12 No. 4, pp.479-491.

Parker, R.H. (1994), "Finding English words to talk about accounting concepts", Accounting, Auditing \& Accountability Journal, Vol. 7 No. 2, pp. 70-85.

Podder-Theising, I. (1984), Hindus Heute. Materialien zu einer Sozialpsychologie der Städtischen Mittelklasse, Peter Lang, Frankfurt a.M..

Popovič, A. (1976), Dictionary for the Analysis of Literary Translation, University of Alberta.

Pritchard, S. (2011) “The readers' editor on... Actor or actress?”, The Guardian, 25 September 2011, available at https://www.theguardian.com/theobserver/2011/sep/25/readers-editor-actor-oractress (accessed 1 August 2017)

Pym, A. (1992/2010), Translation and Text Transfer. An Essay on the Principles of Intercultural Communication, Peter Lang, Frankfurt a.M., Berlin, Bern, New York, Paris and Vienna.

Pym, A. (2014)

Pym, A. and Turk, H. (2001), "Ideology and Translation", in Baker, M. (Ed.) Routledge Encyclopedia of Translation Studies, Routledge, London and New York, pp. 273-7

Quine, W.V.O. (1960) Word and Object, MIT Press, Cambridge, MA.

Quine, W.V.O. (1969), "Linguistics and philosophy", in Hook, S. (Ed.), Language and Philosophy: A Symposium, New York University Press, New York, pp. 95-8. 
Reiss, K. (1986), “Übersetzungstheorien und ihre Relevanz für die Praxis”, Lebende Sprachen, Vol. 31 No 1, pp.1-5.

Reiss, K., and Vermeer, H. J. (1984/(1991), Grundlegung einer allgemeinen Translationstheorie, $2^{\text {nd }}$ ed., Niemeyer, Tübingen.

Roberson, D., Davies, I. and Davidoff, J. (2000), "Color categories are not universal: Replications and new evidence from a stone-age culture, Journal of Experimental Psychology: General, Vol.129, No.3, pp. $369-398$.

Rogowski, R. (1994), "Auditors and lawyers in Germany: Co-evolution, not competition", International Journal of the Legal Profession, Vol.1 No.1, pp.13-29.

Roth, G. (1968), "Introduction", in Weber, M., Economy and Society, University of California Press, Berkeley, CA, pp.xxxiii-cx.

Roth, G. (1992) "Interpreting and translating Max Weber", International Sociology, Vol.7 No.4, pp.449-459.

Rutherford, B. A. (1983), "Spoilt beauty: The true and fair view doctrine in translation", AUTA Association of University Teachers in Accounting Review, Spring, pp. 33-36.

Said, E. (1983), The World, the Text, and the Critic, Harvard University Press, Cambridge, MA.

Sapir, E. (1929/(1949), "The Status of Linguistics as a Science", in Mandelbaum, D. G. (Ed.), Selected Writings of Edward Sapir in Language, Culture, and Personality, University of California Press, Berkeley/Los Angeles, Washington DC.

Saussure, F. (1915/1966), Course in General Linguistics, The Philosophical Library, New York.

Sherry, S. (1996), Gender in Translation. Cultural Identity and the Politics of Transmission, Routledge, London and New York.

Snell-Hornby, M. (1988), Translation Studies: An Integrated Approach, Benjamins, Amsterdam and Philadelphia.

Snell-Hornby, M. (2010), "Mind the GAB”, The Linguist, Vol.49 No.3, pp.18-19.

Spender, D. (1980), Man Made Language, Harper Collins, London.

Spivak, G. (1993/2004), "The politics of translation", in Venuti, L. (Ed.) The Translation Studies Reader, Routledge, London and New York, pp.369-88.

Sun, S. (2014), "Rethinking translation studies", Translation Spaces, Vol.3 No.1, 167-191.

Temple, B. (2013), "Casting a wider net: reflecting on translation in oral history", Oral History, Vol. 41 No. 2, pp. 100-109.

Tietze, S., Piekkari, R., and Brannen, M.Y. (2014), "From standardization to localisation: developing a language-sensitive approach to IHRM", in Collings, D.G., Wood, G.T. and Caliguiri, P.M. (Eds), The Routledge Companion to International Human Resource Management, Routledge, London, pp.482-495.

Toury, G. (1995/2012), Descriptive Translation Studies - and Beyond (2nd ed.), John Benjamins, Amsterdam.

Twain, M. (1880), "The Awful German Language", in Twain, M., A Tramp Abroad, American Publishing Company, pp. 601-619.

Tymoczko, M. and Gentzler, E. (Eds.) (2002), Translation and Power, Univ. of Massachusetts Press, Amherst and Boston.

Venuti, L. (1995/2008), The Translator's Invisibility: A History of Translation, Routledge, Abingdon.

Venuti, L. (1998), The Scandals of Translation: Towards an Ethics of Difference, Routledge, London and New York.

Venuti, L. (Ed.) (1992), Rethinking Translation: Discourse, Subjectivity, Ideology, Routledge, London and New York.

Vermeer, H. J. (1978), "Ein Rahmen für eine allgemeine Translationstheorie", Lebende Sprachen, Vol. 23 No.3, pp.99-102.

von Flotow, L.V. (2000), “Translation and Ideology”, Special Issue of TTR (Traduction, Terminologie, Rédaction), Vol. 13 No.1.

Waisbord, S. (2016), "Communication studies without frontiers? Translation and cosmopolitanism across academic cultures", International Journal of Communication, Vol.10, pp.868-886.

Waters, T. and Waters, D. (2010), "The new Zeppelin University translation of Weber's 'Class, Status, Party”, Journal of Classical Sociology, Vol.10 No.2, pp.153-158. 
Weber, M. (1968), Economy and Society, University of California Press, Berkley, Los Angeles and London.

Werner, O. (1997), "Sapir-Whorf Hypothesis", in Lamarque, P. (Ed.) Concise Encyclopedia of Philosophy of Language, Elsevier, Oxford, New York and Tokyo, pp.76-83.

Winawer, J., Witthoft, N., Frank, M.C., Wu, L., Wade, A.R. and Boroditsky, L. (2007), "Russian blues reveal effects of language on color discrimination", Proceedings of the National Academy of Sciences, Vol. 104 No.19, pp.7780-7785.

Wong, P. H. Y. (2004), Challenges and Successes in Implementing International Standards: Achieving Convergence to IFRSs and ISAs, International Federation of Accountants, New York.

Xian, H. (2008), "Lost in translation? Language, culture and the roles of translator in cross-cultural management research", Qualitative Research in Organizations and Management: An International Journal, Vol. 3 No. 3, pp. 231-245.

Yang, H.H., Craig, R. and Farley, A. (2015), "A review of Chinese and English language studies on corporate environmental reporting in China", Critical Perspectives on Accounting, 28, pp.3048.

Zeff, S. (1990/1994), “The English-language equivalent of Geeft een Getrouw Beeld”, in Parker, R.H. and Nobes C.W. (Eds.), An International View of True and Fair Reporting, Routledge, London/New York, pp. 131-133.

Zeff, S.A. (2007), "Some obstacles to global financial reporting comparability and convergence at a high level of quality", British Accounting Review, Vol. 39 No. 4, pp.290-302. 
1 There is no mention of translation, for example, in The Routledge Companion to Accounting Communication.

${ }^{2}$ In fact, the connation differs even between English English and American English (I am grateful for Reviewer 1 for pointing this out.

3. Pym explains the difference between these levels of equivalence with reference to a translation of "Friday the $13^{\text {th }}$ " into Spanish, where, if this were to be translated with reference to a bad luck, the translation would have to be Tuesday 13th: "Sometimes the value is on the level of form (two words translated as two words); sometimes it is reference (Friday is always the day before Saturday); sometimes it is function (the function 'bad luck on $13^{\text {th }}$, corresponds to Friday in English, to Tuesday in Spanish)" (Pym, 2014, p. 7).

4. Other definitions, classifications and explications are provided for example by Kenny (2001), House (2016, pp. 9-12) and Munday (2008, Chapter 3). Munday (2008) and Pym (2014) in particular provide useful overviews of several traditional theories of equivalence, including those of Catford, Nida, Jakobson, Kade and Koller. See also Kettunen (2017).

5. See for example Saussure (1916/74), Sapir (1929/49), or, for an overview of the Sapir-Whorf hypothesis, Werner (1997).

6. This experiment was conducted on 26 June 2017.

7. Pym (2014, p. 31) notes that, although Nida was assuming natural equivalence, his practical applications were in effect directional. In fact many definitions of equivalence under the natural equivalence paradigm are implicitly directional - the target side is expected to be equivalent to the source, but not vice versa (Pym 2014, p. 27).

8. All official languages have equal legal status to ensure that all citizens have access to legislation, and are able to communicate with the EU, in their own languages (Athanassiou, 2006, EU website (Multilingualism, https://europa.eu/european-union/topics/multilingualism_en accessed 1 August 2017)

9. Arguably, English language proficiency of Board members may have increased since the reconstitution of the IASC as IFRS Foundation. However, the number of members from non-English speaking countries has increased. At the time of writing, only five members are from countries where English is (one of) the official language(s). 10. See Kettunen (2017) for a detailed comparison of the IFRS Foundation's and the EU's translation policies and practices.

11. http://www.ifrs.org/issued-standards/ifrs-translations/\#own (accessed 1 August 2017)

12. See inter alia Dahlgreen and Nilsson (2012), Niehus (2005) and Nobes (2013) for examples of such errors. A common cause of errors relates to faux amis (false friends), which are terms that, in different languages, appear to be similar, but have different meanings. For example, Swedish materiell, French materiel or Romanian material would not be suitable translations of the English term "material" in an accounting context (as in "material error"). See Baskerville and Evans (2011) for other examples from the accounting register.

13. Not surprisingly, Huerta et al. (2013) find that there is greater variation in how generic (i.e. everyday or nontechnical) words or phrases in IFRS are translated by accountants into Spanish than is the case for technical accounting terms - many of which have been standardized in the IFRS Foundation's terminology list.

14. See also Evans (2010) for the implications of adopting loanwords in accounting, and the resulting shifts in meaning.

15. Such perplexing definitions are of course not confined to IFRS. For example, Carnegie and Wines (1992) examine inconsistent asset recognition criteria in Australian accounting pronouncements between 1970 and 1992. These include the terms "beyond reasonable doubt", "virtually certain", "reasonably expected", and "probable". 16. This recent study finds that "there are differences in interpretation of terms of likelihood between Australian and Korean accounting professionals" and that "there may be a translation issue that should be addressed". Such issues include terms that cannot be translated from English into Korean, for example where Korean may only have one term for two English terms denoting different degrees of uncertainty in English, such as "probable" and "likely", or "virtually certain" and "reasonably certain" (KASB and AASB, 2016, p. 39).

17. As noted for example by Komori (2015) for Japan, where younger researchers are turning to quantitative research partly because this is perceived to be less demanding with regard to English language skills. A similar observation is made by Humphrey (2008).

18. This is the case for example in experimental studies using international post-graduate students as subjects, as proxies for audit practitioners or users of financial statements. It is frequently justified with the suggestion that, being educated in English, they have English language skills.

19. Xian (2008) makes this observation for management research. A review of published qualitative accounting research confirms that this is equally the case for cross-cultural accounting research. (Previous work by the author of the present paper is not exempt from this observation.) 
${ }^{20}$ Chidlow et al. (2014) provide a review of literature that critiques back translation. They include in this Brislin's (1970) much-cited paper on back translation, pointing out that Brislin himself warned against the use of back translation in isolation.

${ }^{21}$ Although using the native language was not always perceived as the best solution, with some researchers suggesting that the use of English provided an outsider's advantage (Welch and Piekkari, 2006).

22. To illustrate the problem, a reader may wish to reflect on the potential difficulties inherent in translating into any other language - the following interview extract, from the work of Kathryn Haynes:

"I think the London office was very much geared towards public school and Oxbridge graduates and very Home Counties focused really, so the fact that I had a Yorkshire accent and I don't have a posh accent, I felt, it made me feel, the only way I can explain it is as if I have got dirty fingernails. You know like when you are in the Brownies and you are having your nails checked, and have you got everything in your pocket, it made me feel like that, I felt sort of scruffy and working class and felt I was being looked down on" (Haynes 2008, p. 335, emphases added).

Clearly, the less familiar an audience may be with the cultural context referred to, the harder it will be to translate for this audience. Not only the literal meaning, but also the cultural connotations of the highlighted terms, in their specific temporal and spacial setting, would need to be conveyed. For example, in the UK the term "public school" typically refers not to a state school, as may be assumed, but to an exclusive fee paying private school.

23. Spivak refers to literary translation but, I would argue, this quote is equally pertinent to qualitative accounting research.

24. Ideology has been defined in many different ways: it can refer simply to systems of ideals and principles, but also, more critically, to false beliefs.

25. On translation and ideology, see also, for example, Bassnett and Trivedi (1999), Cunico and Munday (2007), Gentzler and Tymoczko (2002), Venuti (1992), von Flotow (2000).

26. See for example the special issues of Accounting, Auditing \& Accountability Journal on "Accounting and Subalternity" (Volume 22, Issue 3, 2009) or of Critical Perspectives on Accounting on "Accounting and Empire" (Volume 15, Issue 1, 2004).

27. Waisbord (2016, p. 873) refers, for example, to "conventional references to, among others, American and Austrian economics, French and German sociology, and British and American anthropology".

28. An example of this may be French interpretations and adaptation of Hegel - see for example Baugh's (2003) French Hegel: From Surrealism to Postmodernism.

29. Descriptive translation studies aims not to prescribe, but focuses primarily on exploring and describing what translations are. Skopos theory is concerned with the function (skopos) of the translated text in the target culture and applies predominantly to non-literary texts, such as legal, scientific or academic texts (with reference to accounting, see e.g. Evans et al., 2015). 